\title{
Environmental and spatial factors influencing the distribution of cladocerans in lakes across the central Canadian Arctic treeline region
}

\author{
Jon N. SWEETMAN ${ }^{1) *}$, Kathleen M. RÜHLAND and John P. SMOL \\ Paleoecological Environmental Assessment and Research Laboratory (PEARL), Department of Biology, Queen's University, \\ Kingston, Ontario, Canada K7L 3N6 \\ ${ }^{1)}$ Current Address: Western and Northern Service Centre, Parks Canada, 145 McDermot Avenue, Winnipeg, MB, Canada R3B 0R9 \\ *e-mail corresponding author: jon.sweetman@pc.gc.ca
}

\begin{abstract}
We examine the role of local environmental and spatial factors in explaining variation in the composition of cladoceran assemblages from surface sediments within a set of 50 lakes spanning a broad southwest to northeast transect across the central Canadian Arctic treeline region from Yellowknife (Northwest Territories) to the northern boundary of the Thelon Game Sanctuary (Nunavut Territory). Within each lake, the cladoceran fauna was identified based on the subfossil exoskeletal remains preserved in recently deposited lake sediments. Physical and chemical limnological data were measured in August of 1996 and 1998 . Spatial data were generated based on latitude and longitude using Principal Coordinates of Neighbors Matrices analysis (PCNM). The relationships between cladocerans and the measured environmental and spatial variables were examined using both unconstrained (Principal Components Analysis, PCA) and constrained (Redundancy Analysis, RDA) ordination techniques. Variance partitioning, based on partial RDAs, was used to identify the relative importance of significant environmental and spatial explanatory variables. Three environmental variables were identified as significantly influencing cladoceran community structure: surface water temperature, dissolved organic carbon (DOC), and total phosphorus (TP). Five PCNM-generated spatial variables were also significant in explaining cladoceran distributions. Variance partitioning attributed $14 \%$ of the variance in the distribution of Cladocera to spatial factors, an additional 10\% to spatially-structured environmental variables, and $8 \%$ to environmental factors that were not spatially-structured. Within the central Canadian Arctic treeline region, spatial and other environmental processes had an important influence on the distribution of cladoceran communities. The strong influence of spatial factors was related to the large ecoclimatic gradient across treeline. The distribution patterns of cladocerans suggest that they have potential for use in paleoenvironmental assessments of northern ecosystems, a region of considerable interest for environmental change research.
\end{abstract}

Key words: Cladocera, treeline, Northwest Territories, Nunavut, subarctic, paleolimnology

\section{INTRODUCTION}

There has been increasing evidence documenting the impacts of recent climate warming on Arctic and subarctic ecosystems (e.g., Serreze et al. 2000; ACIA 2004; Overland et al. 2004; Hinzman et al. 2005; Smith et al. 2005; Smol et al. 2005; Smol \& Douglas 2007a, b). The effects of climate change are expected to be most severe in high-latitude regions, as feedbacks from decreasing snow cover and melting sea ice will result in accelerated warming in Arctic regions over the next century (Chapin et al. 2005; Serreze \& Francis 2006). Freshwater lakes and ponds are a prominent component of the northern landscape, and climate change is predicted to have significant impacts on aquatic ecosystems. Smol et al. (2005), for example, have shown that many biological communities in Arctic lakes and ponds have already undergone substantial and unprecedented shifts over the past $\sim 150$ years. Understanding how aquatic communities will respond to further climate warming, however, is difficult for many groups of organisms, as little is known about their current distribution within the Arctic, or the factors regulating their occurrence.
The Cladocera (Crustacea: Branchiopoda) are a key group of organisms in many Arctic and subarctic lakes and ponds, comprising an important component of the zooplankton and benthos. While pelagic zooplankton communities have been relatively well studied (e.g., Swadling et al. 2000; O'Brien et al. 2004), information on the distribution of benthic and plant-associated taxa (i.e., Chydoridae) in most regions is limited (e.g., Hebert \& Hann 1986; Korhola 1999; Jeppesen et al. 2001; Sweetman \& Smol 2006a). Currently, very little information exists on the cladoceran communities in the central Canadian Arctic treeline region (Bardach 1954; Reed 1959; Moore 1978). As this region is expected to be one of the most sensitive to environmental change (MacDonald et al. 1998; Serreze et al. 2000; Hinzman et al. 2005; Holtmeier \& Broll 2005), it is important to determine the factors controlling current cladoceran distributions. Moreover, because of the strong climatic and environmental gradients across treeline, high latitude regions represent critical areas to examine how environmental factors influence the distribution of biological communities (Korhola 1999; Swadling et al. 2000; Rühland et al. 2003a, b; Walker et al. 2003). 
Because most Arctic and subarctic lakes are remote and difficult to access, obtaining information on cladoceran communities in these lakes can be challenging. Cladoceran species fluctuate in their abundance seasonally, and occupy a variety of different habitats. As a result, many species are typically overlooked in traditional limnological sampling approaches (Jeppesen et al. 2003; Vandekerkhove et al. 2005). An alternative approach is through the use of paleolimnological methods. By analyzing the remains of cladocerans from the top centimeter of sediment in each lake, taxa deposited over the past few years can be identified. By comparing the distribution of taxa within the surface sediments of each lake with the existing environmental conditions, an understanding of the relationship between the distributions of species in relation to environmental factors can be obtained. The use of sedimentary cladoceran remains to examine environmental relationships has been used successfully in other northern regions, including Finland (Korhola 1999; Korhola et al. 2000), Greenland (Jeppesen et al. 2001; 2003), Alaska (Sweetman \& Smol 2006a), and central British Columbia (Bos \& Cumming 2003), as well as in European alpine regions (Lotter et al. 1997, 1998; Bigler et al. 2006; Heegaard et al. 2006; Brancelj et al. 2008).

Several factors related to climate warming might be predicted to impact the structure of cladoceran communities. Putatively, changes to lake temperatures may have both direct and indirect impacts on cladocerans. In subarctic (Korhola 1999) and alpine (Lotter et al. 1997) regions of Europe, temperature has been shown to be an important factor in structuring cladoceran communities. Climate has also been shown to be an important determinant of more temperate zooplankton communities worldwide (e.g., Patalas 1990; Stemberger et al. 1996; Gyllström et al. 2005). In addition to warmer temperatures and increased precipitation, other environmental factors that may influence cladoceran communities are also predicted to change along with climate warming. These include changes in DOC and UV penetration (Williamson et al. 2001; Rautio \& Korhola 2002; Zellmer et al. 2004), duration of ice cover (Magnuson et al. 2000; Smol et al. 2005; Duguay et al. 2006), changes in water level (Klein et al. 2005; Korhola et al. 2005) and melting permafrost (Jorgenson et al. 2001; Kokelj et al. 2005; Smith et al. 2005), which could result in increases in ion and nutrient concentrations in lakes. We might expect that environmental factors related to climate change would have a strong influence in regulating cladoceran assemblages within Arctic and subarctic regions.

Within the central Canadian Arctic treeline region, Sweetman et al. (2008) reported significant shifts in cladoceran species to have occurred from pre-industrial periods to the present. The observed changes in cladoceran assemblages, however, were subdued compared to shifts in algal communities at the same sites, and recent climate change did not appear to result in concurrent changes in the Cladocera within this region (Sweetman et al. 2008). It may be possible that cladoceran assemblages are more resilient to climate-related environmental shifts, however our knowledge of the role of environmental factors in regulating cladoceran assemblages in northern Canada is limited.

The objectives of this study, therefore, are to determine which environmental and spatial factors are important in influencing cladoceran communities in a series of lakes in the critically sensitive area of the central Canadian Arctic treeline region. Cladocera were identified from the lakes based on their remains from surface sediments. Because of the strong environmental gradients at treeline, we hypothesize that space and spatially-structured environmental variables are potentially important determinants of cladoceran community structure in lakes in this climatically and environmentally sensitive region.

\section{METHODS}

\subsection{Study area}

Our study included 50 lakes located near Arctic treeline in the central Northwest Territories and Nunavut, Canada (Fig. 1), that were previously analyzed for water chemistry variables (Rühland et al. 2003b) and diatom distributions (Rühland \& Smol 2002; Rühland et al. 2003a), and for the response of cladocerans and diatoms to recent environmental changes (Rühland et al. 2003c; Sweetman et al. 2008). The lakes were distributed across a broad southwest to northeast transect between Yellowknife $\left(62^{\circ} 32^{\prime} \mathrm{N}, 114^{\circ} 13^{\prime} \mathrm{W}\right)$ and the northern boundary of the Thelon Game Sanctuary $\left(66^{\circ} 41^{\prime} \mathrm{N}, 104^{\circ} 55^{\prime} \mathrm{W}\right)$. There are strong vegetational and climatic gradients across this transect. As a result, the study lakes are located across three major ecozones, from the boreal forest zone in the south, through the forest-tundra transitional zone, and into the Arctic tundra zone in the north (Rühland \& Smol 2002; Rühland et al. 2003a; Sweetman et al. 2008).

Vegetation in the boreal forest is dominated by coniferous tree species, primarily black spruce (Picea mariana P. Mill.), white spruce (P. glauca (Moench) Voss.), balsam fir (Abies balsamea (L.) P. Mill.), and jackpine (Pinus banksiana Lamb.) (Ritchie 1993). In the forest-tundra transition zone, coniferous trees are also dominant, particularly black spruce, white spruce, and larch (Larix laricina (Du Roi) K. Koch); however, several deciduous trees are also present, including balsam poplar (Populus balsamifera L.), trembling aspen ( $P$. tremuloides Michx.) and paper birch (Betula papyrifera Marsh.) (Sirois 1992). Vegetation in the Arctic tundra consists of mostly sedges (Carex spp. L.), lichen-heath and various dwarf-shrubs (Ritchie 1993).

The climate of the study region is subarctic continental, with long, cold winters, and short, warm summers. There is a gradient of both temperature and precipitation, with warmer seasonal temperatures and 


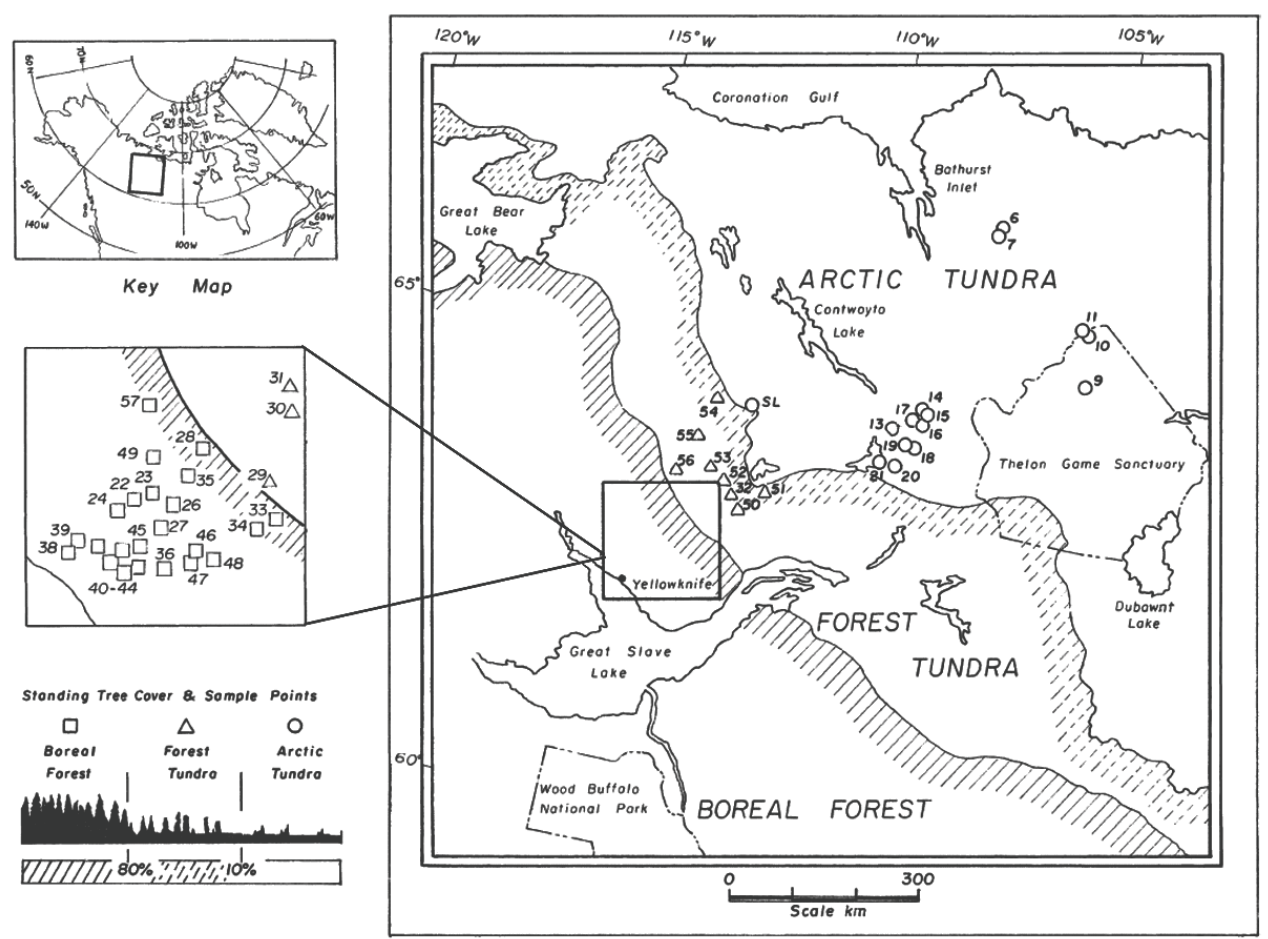

Fig. 1. Location of the 50 study lakes in relation to the position of the arctic treeline. Lake numbers follow those used in Rühland \& Smol (2002) and Rühland et al. (2003a, b, c).

higher annual precipitation occurring in the boreal forest sites in the south, compared to the Arctic tundra sites in the north. In the boreal forest region near Yellowknife, mean daily temperatures range from $16.5^{\circ} \mathrm{C}$ in July to $-27.9{ }^{\circ} \mathrm{C}$ in January, mean annual precipitation is 267 mm (Environment Canada 1990), and the ice-free period on the lakes lasts approximately 120 days (Wedel et al. 1990). The northern tundra sites, in comparison, have mean daily temperatures of $9.9{ }^{\circ} \mathrm{C}$ in July and $-31.4{ }^{\circ} \mathrm{C}$ in January, a mean annual precipitation of 200 $\mathrm{mm}$ (Environment Canada 1990), and an ice-free period of about 90 days (Wedel et al. 1990). The study area is underlain by permafrost, with regions of discontinuous permafrost occurring in the watersheds of the lakes within the boreal forest, and continuous permafrost occurring north of treeline, in the Arctic tundra zone.

With the exception of Slipper Lake (an Arctic tundra site), the lakes were unnamed, and were assigned numbers based on the order of sampling (Rühland 2001). Further information on the geology, vegetation, soils and climate of the study area are provided by Rühland (2001), Rühland \& Smol (2002) and Rühland et al. $(2003 \mathrm{a}, \mathrm{b})$. The physical and chemical characteristics of the lakes are described in detail by Rühland et al. (2003b).

\subsection{Sampling}

We examined the distribution of cladoceran remains from the sediments of a set of 50 lakes used previously to investigate evidence from diatom (Rühland et al. 2003c) and cladoceran (Sweetman et al. 2008) assem- blages for recent environmental change in this region. This lake set was a subset of 77 calibration lakes used to develop diatom-based calibration transfer functions (Rühland \& Smol 2002). Lakes TK6 to TK-36 were sampled in August, 1996; Lakes TK-37 to TK-58 were sampled in August, 1998, and Slipper Lake (SL), a tundra site, was sampled through the ice in March, 1997. Surface sediments from each lake were collected at approximately the deepest point of each lake using a gravity corer (Glew et al. 2001). The top 1-2 cm were sectioned using a Glew (1988) vertical extruder, and transported to Queen's University (Kingston, Ontario), where the sediment was kept in a $4.0^{\circ} \mathrm{C}$ coldroom until analyses of cladoceran remains were performed. Further details on the collection of sediments and limnological data are provided in Rühland \& Smol (2002) and Rühland et al. (2003a, b, c).

\subsection{Preparation and analyses of sediment samples}

Subsamples of sediments from each lake site were processed for cladoceran remains following standard procedures, as described in Korhola \& Rautio (2001). Briefly, sediment was deflocculated in a $10 \% \mathrm{KOH}$ solution and heated at $80{ }^{\circ} \mathrm{C}$ for approximately $30 \mathrm{~min}$ utes. Sediment was then rinsed through a $37 \mu \mathrm{m}$ sieve. The material retained on the sieve was transferred into a small vial with distilled water, and a few drops of ethanol were added to prevent fungal growth. Two to three drops of a safranin-glycerin solution were also added to stain cladoceran remains. $50 \mu \mathrm{L}$ aliquots were pipetted onto slides and counted at $400 \times$ magnification. Entire 
coverslips were enumerated to avoid any bias from unequal distribution of remains on the slide. For each species, the most abundant remain (i.e., head shield, carapace, postabdomen) was used to calculate the number of individuals in a sample (Frey 1986). Slides were counted until a minimum of 50 individuals had been enumerated per lake, a sum that was shown to produce reliable results in other paleo-invertebrate investigations (Heiri \& Lotter 2001; Larocque 2001; Quinlan \& Smol 2001).

\subsection{Taxonomy}

Identification of cladoceran remains was based on several sources, primarily Sweetman and Smol (2006b) as well as Bos (2001), Frey $(1959,1962,1965,1980$, 1985), Hebert (1995), Megard (1967) and Smirnov (1974, 1996). Because the entire organism does not generally preserve intact, but separates into component parts of the exoskeleton (i.e., head shield, shell, and postabdomen), it was not possible to identify some taxa to the species level, based on the remains we recovered. In particular, we had difficulties separating two small species of Alona, A. guttata (Sars 1862) and A. barbulata (Megard 1967), and combined all remains resembling these two species as Alona guttata/barbulata. Similarly, while most remains of the Bosminidae we encountered were likely Bosmina longirostris (Müller 1785), on many head shields the head pores necessary to correctly distinguish them from other bosminids were not visible, so we grouped all Bosmina spp. for the purposes of analyses. Most of the Daphnia remains we found were postabdominal claws of the Daphnia pulex complex, likely Daphnia middendorffiana (Fischer 1851). However, the postabdominal claws of this Daphnia group are indistinguishable from each other, and we classified all Daphnia claws with enlarged teeth in the middle pecten region as belonging to the Daphnia pulex complex (Sweetman \& Smol 2006b).

\subsection{Data Analysis}

Out of the 50 lakes included in this study, insufficient cladoceran remains were recovered from three of the lakes (TK-13, TK-21 and TK-49). As a result, these lakes were excluded from further analyses. In addition, the two most northern sites (TK-6 and TK-7) were found to be outliers in the preliminary ordinations of the spatial data, and were subsequently removed from analyses. Therefore, the final cladoceran data set consisted of 29 taxa occurring in 45 sites, 11 tundra, 11 forest-tundra, and 23 boreal forest lakes. Prior to analyses, the species data were Hellinger-transformed, as suggested by Legendre \& Gallagher (2001), to allow the use of Euclidean-based ordination methods (i.e., Redundancy Analysis, RDA; Principal Components Analysis, PCA). Hellinger-transformations also offer the advantage of not strongly weighting rare taxa in the analyses (Legendre \& Gallagher 2001).
We used PCA, an unconstrained ordination method, to summarize the distribution of cladoceran taxa across our study sites. The PCA represents the full variation in the cladoceran community, and can be useful in comparing to analyses using direct ordination methods (i.e., RDA), where the variation in cladoceran taxa is constrained to explanatory variables. A comparison of the PCA and RDA results allows us to assess how closely our explanatory variables capture the complete variance in the cladoceran data set (Bos \& Cumming 2003).

For constrained ordination methods, we incorporated into our analysis several environmental variables considered to be potentially important in structuring cladoceran communities, including nutrients [total phosphorus unfiltered (TP), total nitrogen (TN), total Kjeldahl nitrogen (TKN)], chlorophyll- $a$, dissolved inorganic carbon (DIC), dissolved organic carbon (DOC), major ions [calcium $(\mathrm{Ca})$, sodium $(\mathrm{Na})$, potassium $(\mathrm{K})$, magnesium $(\mathrm{Mg})$, chloride $(\mathrm{Cl})$, sulfate $\left.\left(\mathrm{SO}_{4}\right)\right]$, specific conductivity (COND), $\mathrm{pH}$, surface water temperature (TEMP), lake depth (DEPTH), and surface area (AREA). Prior to analyses, several of the environmental variables were transformed using either a square-root or $\log (n+1)$ transformation to improve homoscedasticity.

A set of spatial variables were generated through the use of PCNM analysis (Principal Coordinates of Neighbors Matrices: Borcard \& Legendre 2002; Borcard et al. 2004) based on the longitude and latitude of each site. PCNM is a method for detecting and quantifying spatial patterns over a range of different scales. Latitude and longitude were first converted into Cartesian coordinates $(\mathrm{X}, \mathrm{Y})$. Using the $\mathrm{X}$ and $\mathrm{Y}$ coordinates, a matrix of PCNM variables was created using the program SpaceMaker2 (Borcard \& Legendre 2004). A truncation distance of $50 \mathrm{~km}$ was used. This analysis yielded 22 PCNM variables. Because of the irregular pattern of the occurrence of our study sites across the landscape, the PCNM variables do not show regular sine-shaped patterns (Borcard \& Legendre 2002; Borcard et al. 2004), but represent a sequence of broad to medium scale variation across our study area (Fig. 2).

The contribution of both environmental variables and spatial factors in structuring the cladoceran community was assessed through the use of variance partitioning (Borcard et al. 1992). Partitioning was done through partial canonical redundancy analysis (partial RDA) using the program CANOCO version 4.5 (ter Braak \& Šmilauer 2002). To avoid artificially increasing the explanatory power in our analyses through the inclusion of redundant explanatory variables, we first ran a series of partial RDAs constrained to each individual environmental or spatial variable alone. Variables were only retained in the analyses if they explained a significant $(\alpha \leq 0.05)$ amount of variance in the cladoceran data. All significance testing was assessed by Monte Carlo permutation tests using 999 unrestricted permutations in CANOCO version 4.5 (ter 

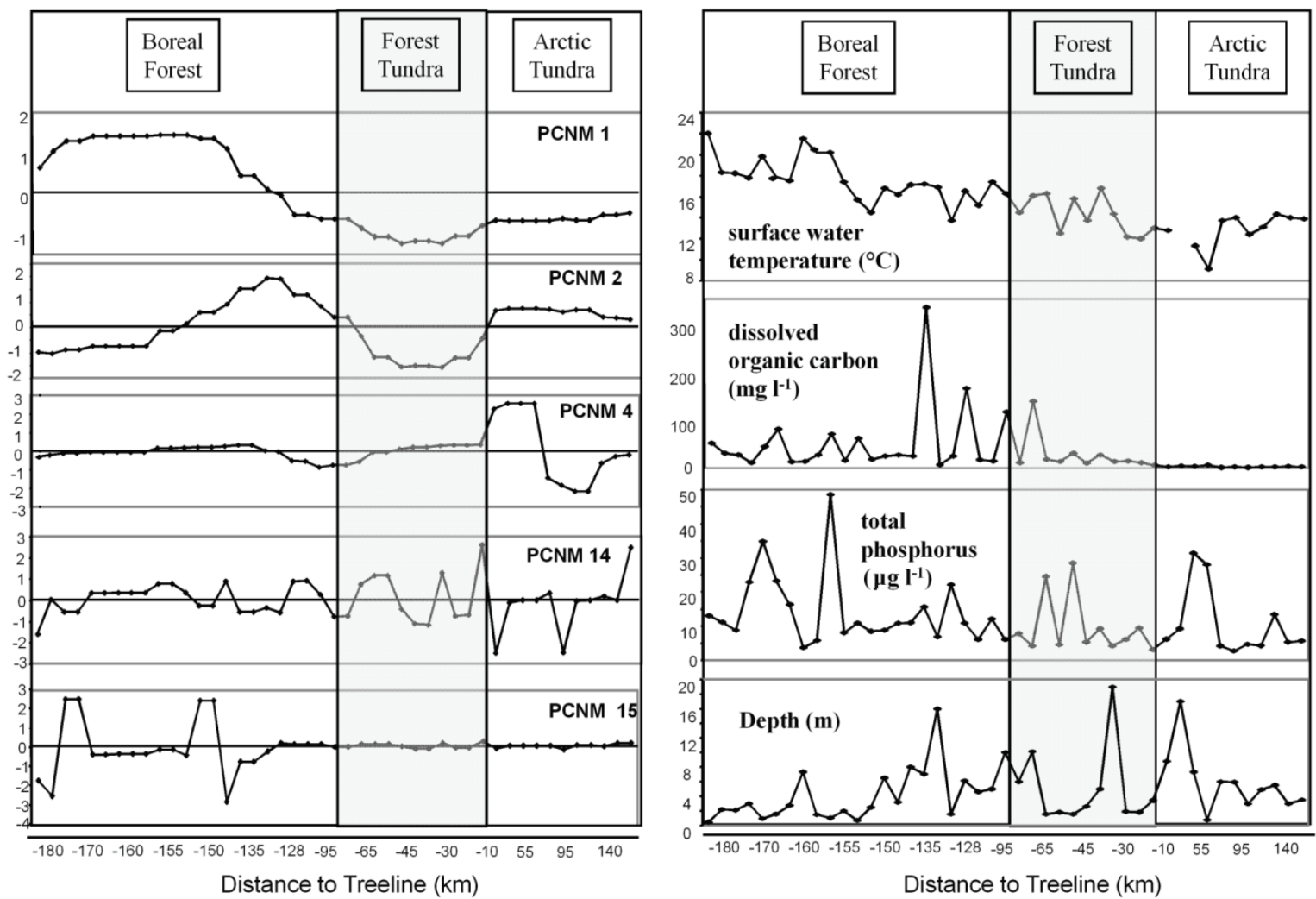

Fig. 2. The distribution of significant spatial and environmental variables across treeline. Lakes are arranged along the $\mathrm{x}$-axis based on distance to treeline $(\mathrm{km})$. Positive distances along the $\mathrm{x}$-axis indicate lakes north of treeline, whereas negative distances indicate lakes south of treeline. Separation of sites into ecozones followed Rühland et al. (2001). Ecozones were delineated based on "percentage tree cover" derived from field observations, topographic maps, and aerial and satellite images. PCNM 1, 2, 4, 14 \& 15 are spatial variables generated by Principal Coordinates of Neighbor Matrices.

Braak \& Šmilauer 2002). Following the exclusion of all non-significant explanatory variables, we then ran two separate RDAs for all the significant environmental and spatial variables remaining. To eliminate collinearity among variables within each category, explanatory variables with the highest variance inflation factor (VIF) were sequentially removed until all VIFs were less than 5 (ter Braak \& Šmilauer 2002). Following this, we ran a forward-selection procedure to select the minimum set of spatial and environmental variables that could explain a significant amount $(\alpha \leq 0.05)$ of variation in the cladoceran data. Finally, a series of partially constrained RDAs were performed using the following groups of variables: 1) only the forward-selected environmental variables; 2 ) only the forward-selected spatial variables; 3) all forward-selected environmental variables, with the forward-selected spatial variables as covariables; 4) all forward-selected spatial variables, with the forward-selected environmental variables as covariables. The variance explained by each of these groups allows us to determine the amount of variance in the cladoceran data that is explained by the environmental data alone, the spatial data alone, by environmental data that is spatially structured, as well as the amount of unexplained variance (Borcard et al. 1992; Legendre \& Legendre 1998).

\section{RESULTS}

The remains of twenty-nine cladoceran taxa were identified from the sediments of our lakes. While most taxa appeared to be widely distributed, and present in lakes from all three ecozones (Fig. 3), some cladoceran groups are more common in certain ecozones. For example, Alona circumfimbriata (Megard 1967), A. quadrangularis (O.F. Müller 1776) and Sida crystallina americana (Korovchinsky 1979) occurred in higher relative abundances in the boreal forest region. Similarly, Graptoleberis testudinaria (Fischer 1848), Pleuroxus trigonellus (O.F. Müller 1785) and Chydorus cf. biovatus only occurred in lakes in the boreal forest (Fig. 3). Alonella nana (Baird 1850), Chydorus piger (Sars 1862) and Eurycercus (Bullatifrons) spp. (Frey 1975) was recorded predominately in the boreal forest and forest tundra, whereas Alonella excisa (Fisher 1854) was found mainly in the Arctic tundra and forest tundra sites (Fig. 3). Among the pelagic cladoceran taxa, members of the Daphnia pulex group were more abundant in the boreal forest lakes, whereas D. longiremis (Sars 1861) was found exclusively in Arctic tundra lakes. The Bosminidae were widely distributed across our sampling transect (Fig. 3). 

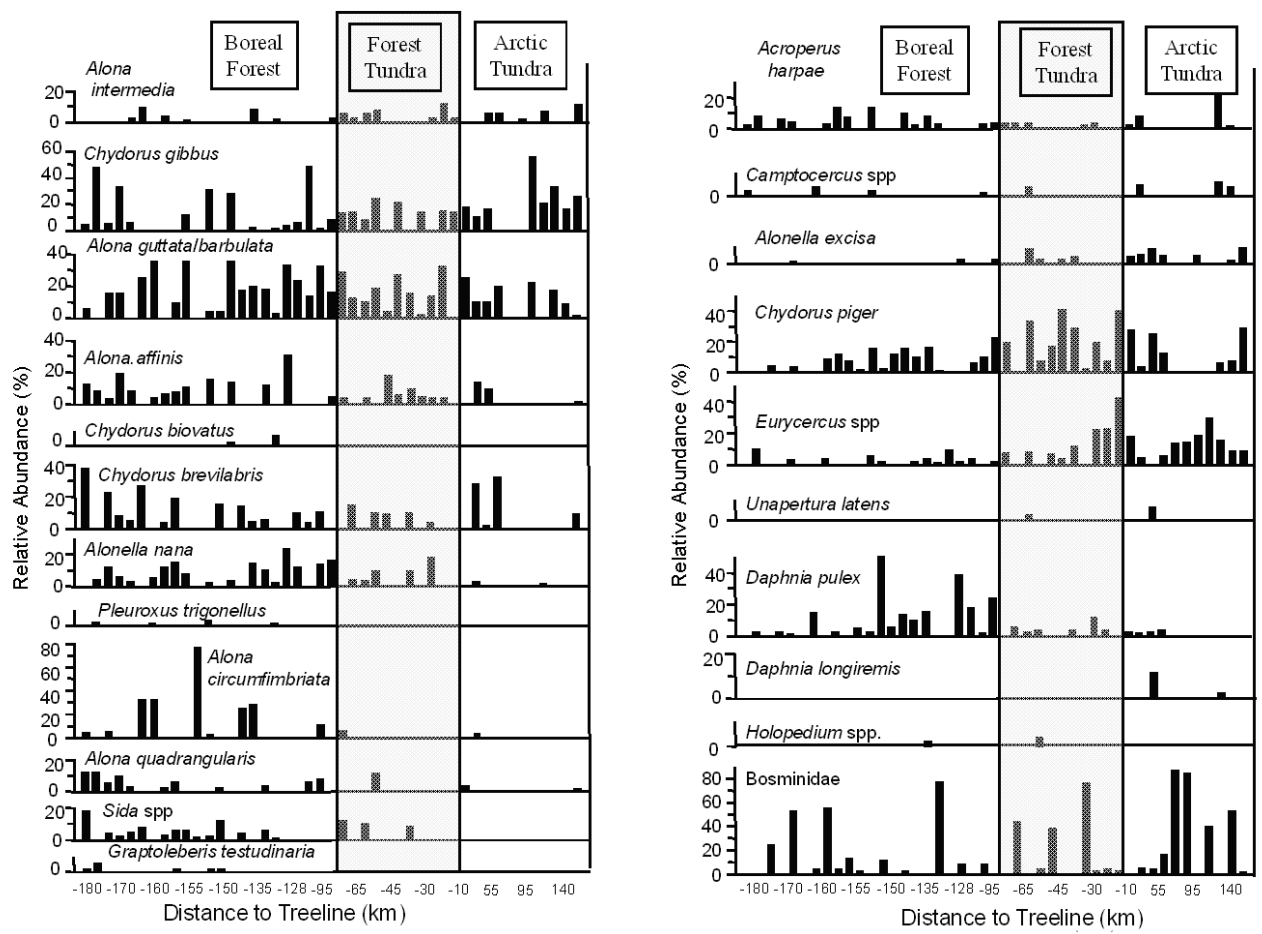

Fig. 3. The distribution and relative abundances of common cladocerans (i.e., those with an abundance of $\geq 2 \%$ in at least 2 lakes) in the study region. Lakes are arranged along the $\mathrm{x}$-axis based on distance to treeline $(\mathrm{km})$. Positive distances along the $\mathrm{x}$-axis indicate lakes north of treeline, whereas negative distances indicate lakes south of treeline. Separation of sites into ecozones followed Rühland et al. (2001). Ecozones were delineated based on "percentage tree cover" derived from field observations, topographic maps, and aerial and satellite images.

\subsection{Unconstrained ordination (PCA)}

Together, PCA axis $1(\lambda=0.249)$ and axis $2(\lambda=$ 0.178 ) explained $42.7 \%$ of the total variance in the cladoceran data. The first two axes show a clear separation of both species (Fig. 4a) and sites (Fig. 4b) within our lake set. The pelagic cladoceran Bosmina spp. were most strongly correlated with the main direction of variation (axis 1), with lakes on the right of the ordination biplot having higher relative abundances of Bosmina (Fig. 4a). These lakes included TK-16 and TK-17 in the Arctic tundra zone, which both had over $80 \%$ relative abundance of Bosmina; lakes TK-53 (forest-tundra transition) and TK-26 (boreal forest), which had Bosmina comprising over $70 \%$ of the relative abundance of cladoceran remains. When environmental variables are passively projected onto the ordination axes (Fig. 4c), depth emerges as being closely correlated with axis 1, with lakes containing high Bosmina abundance tending to be deeper. The spatial variable PCNM14 was also strongly correlated with this axis (Fig. 4c). Axis 2 was strongly correlated with several benthic and plantassociated taxa, as well as the pelagic Daphnia spp. (Fig. 4a). Axis 2 appeared to separate lakes from the boreal forest (top half of the biplot) and lakes in the Arctic tundra and forest-tundra ecozones (bottom half of biplot (Fig. 4b). Axis 2 was strongly correlated with the lake surface water temperature gradient, and also appeared to be closely related to gradients in nutrients (TP), DOC, and specific conductivity (Fig. 4c). Two spatial variables, PCNM1 and PCNM4 also appear to be correlated with this gradient (Fig. 4c). Taxa that tended to be more abundant in the boreal forest environment included Alona circumfimbriata (Megard 1967), Chydorus brevilabris (Frey 1980), Sida crystallina americana, and members of the Daphnia pulex complex. Taxa more abundant in the tundra and forest-tundra transition regions included Chydorus gibbus (Sars 1890) and Eurycercus spp. (Fig. 4a).

\subsection{Constrained ordination ( $R D A)$}

When the relationship between environmental variables and Cladocera is examined through direct ordination methods (i.e., RDA), the most noticeable difference between the RDA and PCA performed on the same cladoceran data set is a reversal of the two main axes (Fig. 5). A comparison of the species and site scores for the RDA and PCA shows that both species and site scores for RDA axis $1(\lambda=0.125)$ are significantly correlated with those of PCA axis 2 (Tab. 1). Similarly, the species and site scores for RDA axis $2(\lambda=0.082)$ are significantly correlated with PCA axis 1 (Tab. 1). The greatest source of variation in our cladoceran data is related to the gradient in bosminid relative abundance. 


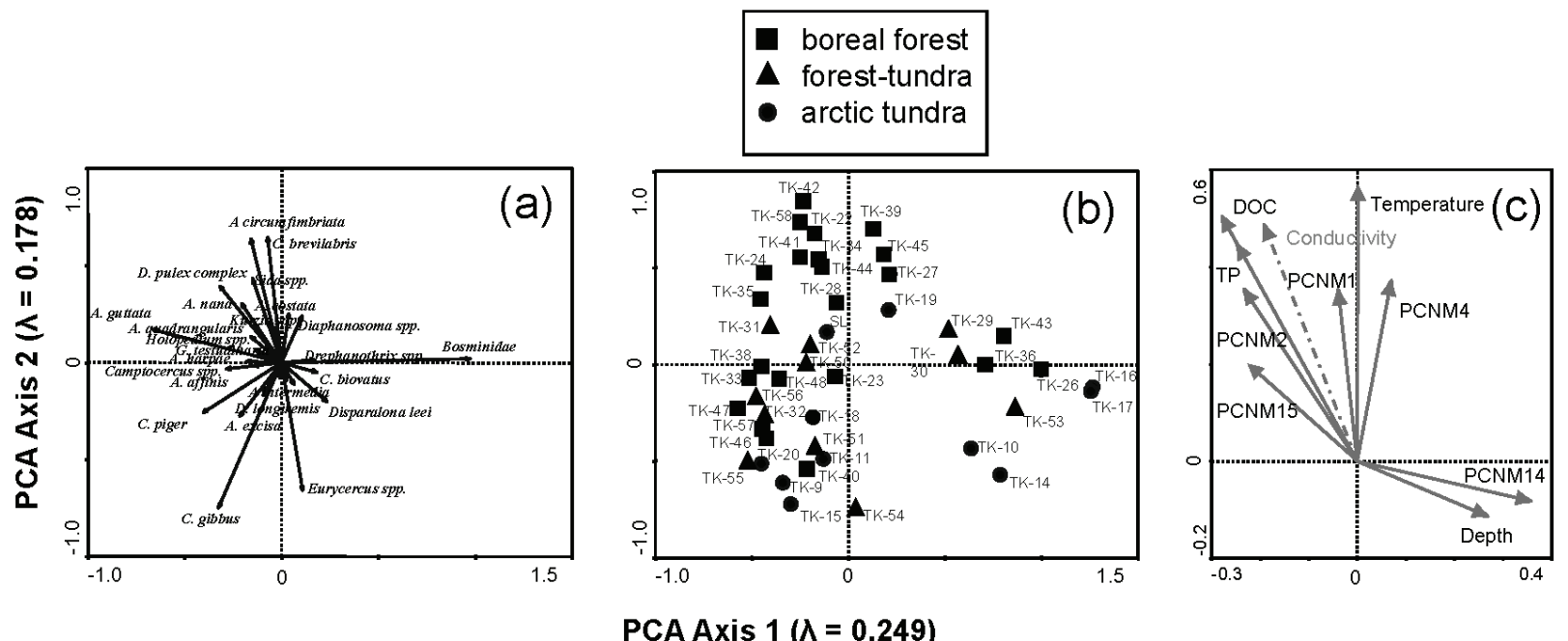

Fig. 4. Principal Components Analysis (PCA) biplots for axes 1 and 2 showing: a) cladoceran species, b) study sites, c) environmental and spatial variables passively projected onto axes. Axes are derived from the variation in the species data matrix; vectors for the environmental variables are their correlations to the axes and have no influence on the placement of the species or sites.
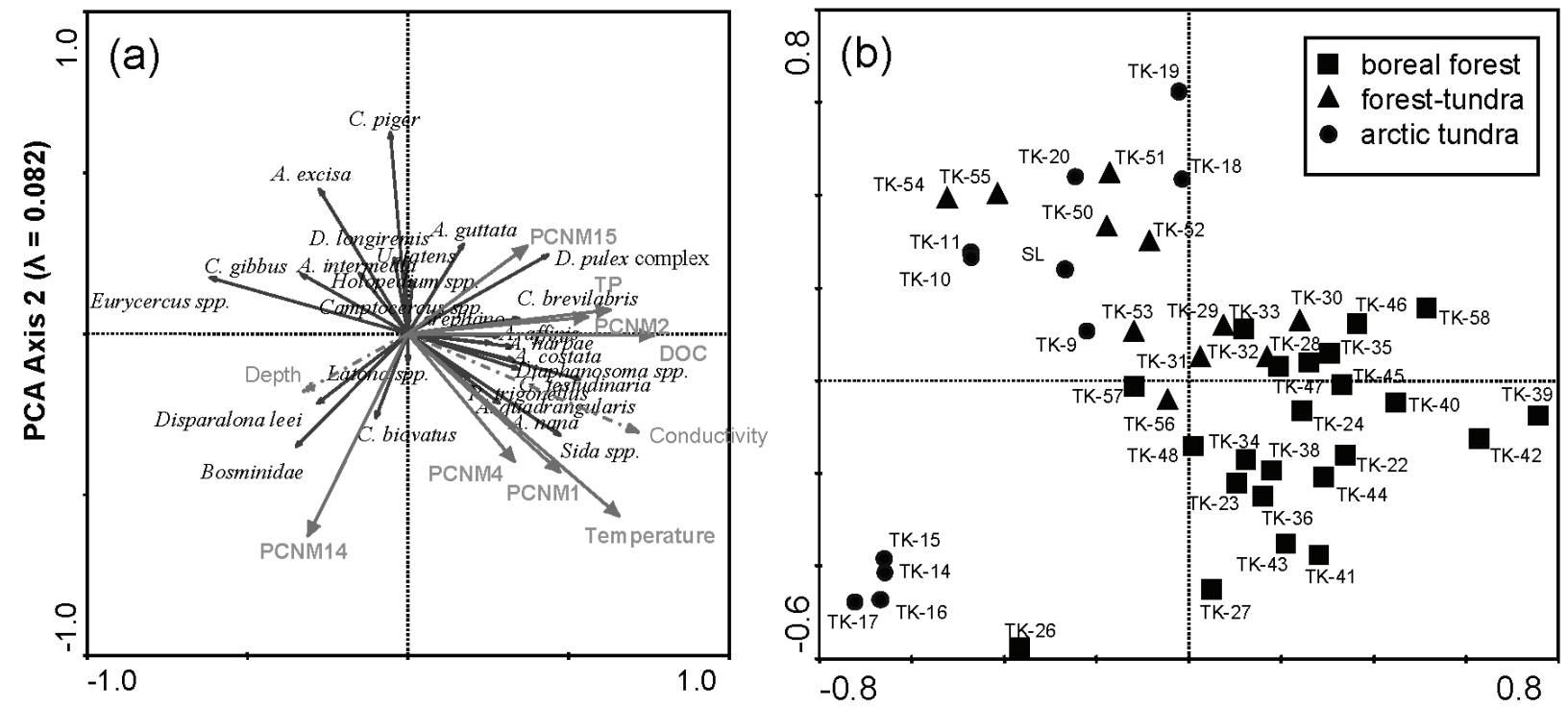

RDA Axis $1(\lambda=0.125)$

Fig. 5. Redundancy Analysis (RDA) biplots showing: a) cladoceran taxa and environmental and spatial variables, and b) study sites. Solid arrows indicate significant variables based on forward selection in RDA $(p<0.01)$, while dotted arrows indicate non-significant variables that are of ecological interest are plotted passively in the ordination.

Tab. 1. Coefficient of determination $\left(r^{2}\right)$ describing correlations between PCA and RDA species and site scores. ${ }^{*}$ significant at $\alpha=0.05$.

\begin{tabular}{lcc}
\hline & RDA sp. axis 1 & RDA sp. axis 2 \\
\hline PCA sp. axis 1 & -0.37 & -0.53 \\
PCA sp. axis 2 & $0.84^{*}$ & -0.38 \\
PCA site axis 1 & -0.59 & $-0.85^{*}$ \\
PCA site axis 2 & $0.79^{*}$ & -0.35 \\
\hline
\end{tabular}

Our measured variables, however, are much better descriptors of the second-greatest direction of variation in the species, which is closely correlated with gradients in temperature, DOC, nutrients and ions (Fig. 4, 5).

Forward-selection in RDA identified 3 environmental variables that were significant in explaining a portion of the variation in the cladoceran distribution within these lakes, namely temperature, total phosphorus (TP), and DOC (Fig. 5a). Conductivity and maximum depth, which were not significant in the forward- 


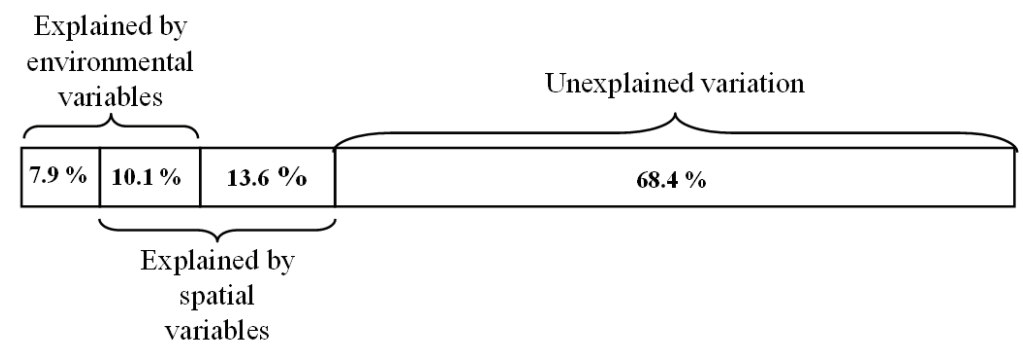

Fig. 6. Variance partitioning results illustrating the proportion of variation in the cladoceran data explained by forward-selected environmental variables, forward-selected spatial variables, and unexplained variation.

selection procedure, are plotted as supplementary variables (i.e., they do not have any influence on the ordination). Conductivity was correlated with temperature, DOC, and TP, but did not contribute significant additional information to the RDA, and therefore was removed from the analysis. Depth was not significant in the overall ordination, but was significantly correlated with Bosmina abundance (Pearson correlation, $r=0.41$; $p=0.005$ ), and is shown for reference purposes. Of the 22 PCNM spatial variables, five were significant in forward-selection procedures of the RDA: PCNM1, 2, 4, 14, and 15 (Fig. 5a).

\subsection{Variance partitioning (partial RDAs)}

Using the two subsets of forward-selected environmental and spatial variables, we used variance partitioning (Borcard et al. 1992; Legendre \& Legendre 1998) to separate the amount of variance in the cladoceran taxa each group could explain. Spatial and environmental variables together could account for $31.6 \%$ of the variation in Cladocera within our study lakes (Fig. 6). $7.9 \%$ was attributed to "pure" environmental variation (non-spatially structured environmental factors), $13.6 \%$ in "pure" spatial variation, and $10.1 \%$ by spatially structured components of the environmental variables included in the analysis. $68.4 \%$ of the variation in Cladocera was unexplained by either the spatial or environmental variables considered in the analysis.

\section{DISCUSSION}

Most species of cladocerans we recorded in our lake set were widely distributed across the study region, occurring in all three ecozones. The diversity of species recorded in our subarctic treeline lakes was very similar to the cladoceran fauna previously reported from lakes in Alaska (Sweetman \& Smol 2006a). The similarity of the cladoceran assemblages that we encountered in our Canadian lakes to the Alaskan fauna, and the widespread occurrence of most species across the sampling transect, suggests that dispersal is probably not a factor limiting the occurrence of cladocerans in northern lakes. Recently, several authors have suggested that cladocerans have a relatively high dispersal capacity (i.e., Havel \& Shurin 2004; Louette \& DeMeester 2005). In contrast, Hebert \& Hann (1986) found that ponds in the Canadian Arctic contained microcrustacean assem- blages that were much less diverse than those in northern Alaska. They suggested that dispersal from the western Beringian refugium was likely limited. Hebert and Hann's (1986) investigation, however, included more dispersal-limited taxa, such as copepods, whereas our study only examined Cladocera. Cladocerans appear to have fairly widespread distributions in northern ecoregions in Western Canada and Alaska.

One cladoceran taxon, Unapertura latens (SarmajaKorjonen et al. 2000), which we found in our sites in the central Canadian treeline region, was not found in our Alaskan lakes (Sweetman \& Smol 2006a), nor has it been previously reported within any lakes in North America. To date, U. latens has only been reported in lakes in Finland (Sarmaja-Korjonen et al. 2000). Our discovery of $U$. latens in North America lakes suggests a much larger range than previously thought for this species, with a possible circumpolar distribution.

Despite the extensive distributions of most taxa within our lakes, there were distinct differences in the relative abundance of cladocerans across ecozones, suggesting that factors other than dispersal may influence cladoceran abundances in subarctic lakes. We found that three environmental variables (lake water temperature, nutrients, and dissolved organic carbon) could explain a significant amount of the variation in cladoceran community structure across the central Canadian Arctic treeline. These three variables are strongly associated with the steep north-south ecoclimatic gradient associated with treeline, where lakes in the boreal forest are typically warmer, more nutrient rich, and have higher concentrations of DOC than lakes in the forest-tundra and Arctic tundra ecozones (Rühland et al. 2003b). The strong relationship of cladoceran communities to climate-related variables suggests that the Cladocera should be sensitive indicators of both past and future climate change, and valuable ecological and paleolimnological monitoring tools. However, a regional assessment of changes in cladoceran composition from preindustrial periods to present (Sweetman et al. 2008) found that, although significant changes in cladoceran species were observed in the last few centuries, the response of cladocerans to climate warming was subtle and muted compared to other paleolimnological indicators.

Interestingly, however, despite the lack of a strong response to recent climate warming within our study 
lakes (Sweetman et al. 2008), surface water temperature was the environmental variable that explained the greatest proportion of variation in the distribution of Cladocera. Temperature has been identified previously as an important factor in regulating cladoceran assemblages in other northern regions, including Finnish Lapland (Korhola 1999; Sarmaja-Korjonen et al. 2006), Norway (Hessen et al. 2006) and the Yukon Territory (Swadling et al. 2000). Increased water temperatures could result in increased mortality or reproductive failure for coldadapted taxa (Moore et al. 1996). Moore (1978) determined that temperature had a significant influence on the diversity, abundance, and fecundity of zooplankton species in a set of 18 lakes in the Northwest Territories. Temperature has also been found to be an important explanatory variable in structuring cladoceran assemblages in alpine lakes within Europe (Lotter et al. 1997; Bigler et al. 2006; Heegaard et al. 2006), where past temperatures have been reconstructed using cladoceranbased quantitative inference models (Lotter et al. 2000; Duigan \& Birks 2000).

A second environmental factor that was identified as important in influencing cladoceran distribution in our treeline lakes was DOC. Within our lake set, there was a large gradient in DOC, as lakes in the boreal forest receive much higher inputs of allochthonous humic matter compared to tundra lakes (Rühland et al. 2003a, b). DOC has an important role in the attenuation of UV radiation, and not only reduces direct mortality in zooplankton from UV radiation, but decreases predation from visual-based predators, such as fish (Wissel et al. 2003; Persaud \& Williamson 2005). Differences in lakewater DOC concentrations has been shown previously to affect zooplankton community structure in Arctic and subarctic regions (e.g., Williamson et al. 2001; Rautio \& Korhola 2002; Zellmer et al. 2004; Hessen et al. 2004), and so it is not surprising that DOC was identified as an important variable in structuring cladoceran communities in our treeline lakes. With future climate change, synergistic effects of changing DOC levels, UV exposure, and changing temperatures may alter food web dynamics considerably (Persaud \& Williamson 2005; Cooke et al. 2006).

Total phosphorus was also identified as being an important measured variable in explaining the distribution of cladoceran taxa within our lake set. TP has previously been recognized as an important variable in structuring cladoceran communities in other regions (e.g., Brodersen et al. 1998; Lotter et al. 1998; Bos \& Cumming 2003; Gyllström et al. 2005; Sweetman \& Smol 2006a). Although most lakes in our study were oligotrophic, there was a notable latitudinal gradient in nutrients across our study transect, with boreal forest lakes tending to have higher TP concentrations than those in the tundra or forest tundra regions (Rühland et al. 2003b). Arctic tundra lakes are typically oligotrophic and nutrient limited (Levine \& Whalen 2001), but nutri- ent loading to these lakes is predicted to increase with climate warming (Prowse et al. 2006). O'Brien et al. (2005) found that primary productivity and Daphnia populations increased following experimental fertilization to half of a partitioned Arctic lake. Future changes in nutrient concentrations in northern lakes will also likely have strong impacts on cladoceran community composition.

Given the strong latitudinal gradients in vegetation and climate across treeline, it was not surprising that a large component of the explained variation was related to spatial factors. Together, spatially-structured environmental variables and "pure" spatial variation (i.e., independent spatial effects) accounted for $23.7 \%$ of the variation in cladoceran assemblages, whereas non-spatial variability captured only $7.9 \%$ of the variation in Cladocera. Water chemistry and temperature show strong latitudinal gradients, which has been observed in several treeline studies (Pienitz et al. 1997; GregoryEaves et al. 2000; Rühland \& Smol 2002; Rühland et al. 2003b). Unmeasured environmental factors, such as macrophyte abundance or predation regimes, may also be captured by the "pure" spatial component.

One probable source of variation in cladoceran communities within these lakes which we could not account for in our analysis is predation and trophic interactions. Several studies have linked regulation of zooplankton in Arctic lakes by either predation by fish (e.g., Jeppesen et al. 2003; O'Brien et al. 2004) or invertebrates (O'Brien 2001; Wissel et al. 2003). There is little information on potential fish and invertebrate predator communities in our study lakes, although we found the remains of Chaoborus mandibles in several of these lakes (Sweetman \& Smol 2006c).

Another factor that would have an important influence on cladoceran distributions is habitat availability. Many of the benthic and plant-associated taxa (e.g., chydorids) have strong habitat preferences (Tremel et al. 2000). The low abundance and diversity of chydorid fauna in many tundra ponds may be due to inadequate availability of substrate (Hebert \& Hann 1986; Sweetman \& Smol 2006a). Longer growing seasons and increased temperatures could result in greater habitat diversity, such as increased macrophyte abundance in Arctic lakes, which could have a large impact on cladoceran communities.

\section{CONCLUSIONS}

The distributional patterns of cladoceran taxa in the 50 study lakes from the central Canadian Arctic treeline region are clearly related to the strong ecoclimatic gradient that occurs across treeline. We recorded distinct assemblages of Cladocera within the boreal forest, forest-tundra and Arctic tundra ecozones. Cladoceran distributions showed the strongest relationships to three environmental variables (lake water temperature, dissolved organic carbon, nutrients) that varied substan- 
tially across treeline, and that are expected to change significantly in response to future climate warming. Spatial variability accounted for a large component $(23.7 \%)$ of the variation in cladoceran communities within our study lakes, with spatially-structured environmental variables accounting for $10.1 \%$, and a "pure" spatial component contributing an additional 13.6\%. Future climate warming is likely to result in a restructuring of the forest-tundra transitional region and, as a result, large changes in cladoceran community structure may be expected.

\section{ACKNOWLEDGEMENTS}

This research was supported by an NSERC grant to J.P. Smol, an NSERC special collaborative grant to the Paleoecological Analysis of Circumpolar Treeline (PACT), and the Northern Studies Training Program (NSTP). Logistical support during sample collection was provided by the Polar Continental Shelf Project. Assistance in the field was also provided by the Department of Indian Affairs and Northern Development (DIAND). Tammy Karst, Tamsin Laing, Brent Wolfe, and Dave Porinchu assisted in field work. Water chemistry analyses were facilitated by Xiaowa Wang and Derek Muir at the National Water Research Institute, Burlington, ON. Thanks to John Glew for creating the map used in figure 1.

\section{REFERENCES}

ACIA. 2004. Impacts of a Warming Arctic: Arctic Climate Impact Assessment. Cambridge University Press, Cambridge: $1042 \mathrm{pp}$.

Bardach, J.E. 1954. Plankton Crustacea from the Thelon watershed, N.W.T. Can. Field Nat., 68: 47-52.

Bigler, C., O. Heiri, R. Krskova, A.F. Lotter \& M. Sturm. 2006. Distribution of diatoms, chironomids and Cladocera in surface sediments of thirty mountain lakes in southeastern Switzerland. Aquat. Sci., 68: 154-171.

Borcard, D. \& P. Legendre. 2002. All-scale spatial analysis of ecological data by means of principal coordinates of neighbour matrices. Ecol. Model., 153: 51-68.

Borcard, D., P. Legendre \& P. Drapeau. 1992. Partialling out the spatial component of ecological variation. Ecology, 73: 1045-1055.

Borcard, D., P. Legendre, C. Avois-Jacquet \& H. Tuomisto. 2004. Dissecting the spatial structure of ecological data at multiple scales. Ecology, 85: 1826-1832.

Borcard, D. \& P. Legendre. 2004. SpaceMaker 2. http:// www.bio.umontreal.ca/casgrain/en/labo/spacemaker.html.

Bos, D.G. 2001. Sedimentary cladoceran remains, a key to interpreting past changes in nutrients and trophic interactions. Ph.D. thesis, Queen's University, Kingston, Ontario, Canada.

Bos, D.G. \& B.F. Cumming. 2003. Sedimentary cladoceran remains and their relationship to nutrients and other limnological variables in 53 lakes from British Columbia, Canada. Can. J. Fish. Aquat. Sci., 60: 1177-1189.

Brancelj, A., M. Kernan, E. Jeppesen, M. Rautio, M. Manca, M. Siško, M. Alonso \& E. Stuchlík. 2008. Cladocera remains from the sediments of remote cold lakes: a study of 294 lakes across Europe. Advanc. Limnol., 62: 239-264.

Brodersen, K.P., M.C. Whiteside, C. Lindegaard. 1998. Reconstruction of trophic state in Danish lakes using subfossil chydorid (Cladocera) assemblages. Can. J. Fish. Aquat. Sci., 55: 1093-1103.
Chapin, F.S., M. Sturm, M.C. Serreze, J.P. McFadden, J.R. Key, A.H. Lloyd, A.D. McGuire, T.S. Rupp, A.H. Lynch, J.P. Schimel, J. Beringer, W.L. Chapman, H.E. Epstein, E.S. Euskirchen, L.D. Hinzman, G. Jia, C.L. Ping, K.D. Tape, C.D.C. Thompson, D.A. Walker \& J.M. Welker. 2005. Role of land-surface changes in Arctic summer warming. Science, 310: 657-660.

Cooke, S.L., C.E. Williamson, B.R. Hargreaves, D.P. Morris. 2006. Beneficial and detrimental interactive effects of dissolved organic matter and ultraviolet radiation on zooplankton in a transparent lake. Hydrobiologia, 568:15-28.

Duguay, C.R., T.D. Prowse, B.R. Bonsal, R.D. Brown, M.P. Lacroix \& P. Menard. 2006. Recent trends in Canadian lake ice cover. Hydrol. Process., 20: 781-801.

Duigan, C.A. \& H.H. Birks. 2000. The late-glacial and earlyHolocene palaeoecology of cladoceran microfossil assemblages at Kråkenes, western Norway, with a quantitative reconstruction of temperature changes. J. Paleolimnol., 23: 67-76.

Environment Canada. 1990. The Climates of Canada. Canadian Government Publishing Centre, Ottawa: 159 pp.

Frey, D.G. 1959. The taxonomic and phylogenetic significance of the head pores of Chydoridae (Cladocera). Int. Rev. ges. Hydrobiol., 44: 27-50.

Frey, D.G. 1962. Supplement to: The taxonomic and phylogenetic significance of the head pores of Chydoridae (Cladocera). Int. Rev. ges. Hydrobiol., 47: 603-609.

Frey, D.G. 1965. Differentiation of Alona costata Sars from two related species (Cladocera, Chydoridae). Crustaceana, 8: 159-173.

Frey, D.G. 1980. On the plurality of Chydorus sphaericus (O. F. Muller) (Cladocera, Chydoridae), and designation of a neotype from Sjaelso, Denmark. Hydrobiologia, 69: 83-123.

Frey, D.G. 1985. A new species of the Chydorus sphaericus group (Cladocera, Chydoridae) from western Montana. Int. Rev. ges. Hydrobiol., 70: 3-20.

Frey, D.G. 1986. Cladocera analysis. In: B.E. Berglund (Ed.), Handbook of Holocene Palaeoecology and Palaeohydrology. John Wiley and Sons, New York: 667-692.

Glew, J.R. 1988. A portable extruding device for close interval sectioning of unconsolidated core samples. J. Paleolimnol., 1: 235-239.

Glew, J.R., J.P. Smol \& W.M. Last. 2001. Sediment core collection and extrusion. In: W.M. Last \& J.P Smol (Eds), Tracking Environmental Change Using Lake Sediments. Vol 1: Basin Analysis, Coring, and Chronological Techniques. Kluwer Academic Publishers, Dordrecht: 73-105.

Gregory-Eaves, I., J.P. Smol, B.P Finney, D.R.S. Lean, \& M.E. Edwards. 2000. Characteristics and variation in lakes along a north-south transect in Alaska. Arch. Hydrobiol., 147:193-223.

Gyllström, M., L.A. Hansson, E. Jeppesen, F. Garcia-Criado, E. Gross, K. Irvine, T. Kairesalo, R. Kornijow, M.R. Miracle, M. Nykänen, T. Nõges, S. Romo, D. Stephen, E. Van Donk \& B. Moss. 2005. The role of climate in shaping zooplankton communities of shallow lakes. Limnol. Oceanogr., 50: 2008-2021.

Havel, J.E. \& J.B. Shurin. 2004. Mechanisms, effects, and scales of dispersal in freshwater zooplankton. Limnol. Oceanogr., 49: 1229-1238.

Hebert, P.D.N. 1995. The Daphnia of North America: An Illustrated Fauna. CD-ROM. Department of Zoology, University of Guelph, Guelph, ON, Canada.

Hebert, P.D.N. \& B. Hann 1986. Patterns in the composition of Arctic tundra pond microcrustacean communities. Can. J. Fish. Aquat. Sci., 43: 1416-1425.

Heegaard, E., A. Lotter \& H. Birks. 2006. Aquatic biota and the detection of climate change: Are there consistent aquatic ecotones? J. Paleolimnol., 35: 507-518. 
Heiri, O. \& A.F. Lotter. 2001. Effect of low count sums on quantitative environmental reconstructions: an example using subfossil chironomids. J. Paleolimnol., 26: 343-350.

Hessen, D.O., P. Blomqvist, G. Dahl-Hansen, S. Drakare \& E.S. Lindstrom. 2004. Production and food web interactions of Arctic freshwater plankton and responses to increased DOC. Arch. Hydrobiol., 15: 289-307.

Hessen, D.O., B.A. Faafeng, V.A. Smith, V. Bakkestuen \& B. Walseng 2006. Extrinsic and intrinsic controls of zooplankton diversity in lakes. Ecology, 87: 433-443.

Hinzman, L.D., N.D. Bettez, W.R. Bolton, F.S. Chapin, M.B.Dyurgerov, C.L. Fastie, B. Griffith, R.D. Hollister, A. Hope, H.P. Huntington, A.M. Jensen, G.J. Jia, T. Jorgenson, D.L. Kane, D.R. Klein, G. Kofinas, A.H. Lynch, A.H. Lloyd, A.D. McGuire, F.E. Nelson, W.C. Oechel, T.E. Osterkamp, C.H. Racine, V.E . Romanovsky, R.S. Stone, D.A. Stow, M.Sturm, C.E. Tweedie, G.L. Vourlitis, M.D.Walker, D.A. Walker, P.J. Webber, J.M. Welker, K. Winker \& K.Yoshikawa. 2005. Evidence and implications of recent climate change in northern Alaska and other arctic regions. Clim. Change, 72: 251-298.

Holtmeier, F. \& G. Broll. 2005. Sensitivity and response of northern hemisphere altitudinal and polar treelines to environmental change at landscape and local scales. Global Ecol. Biogeogr., 14: 395-410.

Jeppesen, E., P. Leavitt, L. De Meester \& J.P. Jensen. 2001. Functional ecology and palaeolimnology: using cladoceran remains to reconstruct anthropogenic impact. Trends Ecol. Evol., 16: 191-198.

Jeppesen, E., J.P. Jensen, T.L. Lauridsen, S.L. Amsinck, K. Christoffersen, M. Sondergaard \& S.F. Mitchell. 2003. Sub-fossils of cladocerans in the surface sediment of 135 lakes as proxies for community structure of zooplankton, fish abundance and lake temperature. Hydrobiologia, 491: 321-330.

Jorgenson, M.T., C.H. Racine, J.C. Walters \& T.E. Osterkamp. 2001. Permafrost degradation and ecological changes associated with a warming climate in central Alaska. Clim. Change, 48: 551-579.

Klein, E., E.E. Berg, \& R. Dial. 2005. Wetland drying and succession across the Kenai Peninsula Lowlands, southcentral Alaska. Can. J. For. Res., 35: 1931-1941.

Kokelj, S.V., R.E. Jenkins, D. Milburn, C.R. Burn \& N. Snow. 2005. The influence of thermokarst disturbance on the water quality of small upland lakes, Mackenzie Delta Region, Northwest Territories, Canada. Permafrost Periglac., 16: 343-353.

Korhola, A. 1999. Distribution patterns of Cladocera in subarctic Fennoscandian lakes and their potential in environmental reconstruction. Ecography, 22: 357-373.

Korhola, A., H. Olander \& T. Blom. 2000. Cladoceran and chironomid assemblages as qualitative indicators of water depth in subarctic Fennoscandian lakes. J. Paleolimnol., 24: 43-54.

Korhola, A. \& M. Rautio. 2001. Cladocera and other branchiopod crustaceans. In: Smol, J.P., H.J.B. Birks \& W.M. Last (Eds), Tracking Environmental Change Using Lake Sediments, Volume 4: Zoological Indicators. Kluwer Academic Publishers, Dordrecht: 240 pp.

Korhola, A., M. Tikkanen \& J. Weckstrom. 2005. Quantification of Holocene lake-level changes in Finnish Lapland using a Cladocera - lake depth transfer model. J. Paleolimnol., 34: 175-190.

Larocque, I. 2001. How many chironomid head capsules is enough? A statistical approach to determine sample size for paleoclimatic reconstruction. Palaeogeogr. Palaeoclimatol. Palaeoecol., 172: 133-142.

Legendre, P. \& E.D. Gallagher 2001. Ecologically meaningful transformations for ordination of species data. Oecologia, 129: $271-280$
Legendre, P. \& L. Legendre 1998. Numerical ecology. $2^{\text {nd }}$ ed. Elsevier, Amsterdam: $853 \mathrm{pp}$.

Levine, M.A. \& S.C. Whalen. 2001. Nutrient limitation of phytoplankton production in Alaskan Arctic foothill lakes. Hydrobiologia. 455: 189-201.

Lotter, A.F., H.J.B. Birks, W. Hofmann, \& A. Marchetto. 1997. Modern diatom, Cladocera, chironomid, and chrysophyte cyst assemblages as quantitative indicators for the reconstruction of past environmental conditions in the Alps. I. Climate. J. Paleolimnol., 18: 395-420.

Lotter, A.F., H.J.B. Birks, W. Hofmann, \& A. Marchetto 1998. Modern diatom, Cladocera, chironomid, and chrysophyte cyst assemblages as quantitative indicators for the reconstruction of past environmental conditions in the Alps. II. Nutrients J. Paleolimnol., 19: 443-463.

Lotter, A.F., H.J.B. Birks, U. Eicher, W. Hofmann, J. Schwander \& L. Wick. 2000. Younger Dryas and Allerod summer temperatures at Gerzensee (Switzerland) inferred from fossil pollen and cladoceran assemblages. Palaeogeogr., Palaeoclimatol., Palaeoecol., 159: 349-361.

Louette, G. \& L. De Meester. 2005. High dispersal capacity of cladoceran zooplankton in newly founded communities. Ecology, 86: 353-359.

MacDonald, G.M., J.M. Szeicz, J. Claricoates \& K.A.Dale. 1998. Response of the central Canadian treeline to recent climatic changes. Ann. Assoc. Am Geog., 88: 183-208.

Magnuson, J.J., D.M. Robertson, B.J. Benson, R.H. Wynne, D.M. Livingstone, T. Arai, R.A. Assel, R.G. Barry, V. Card, E. Kuusisto, N.G. Granin, T.D. Prowse, K.M. Stewart \& V.S. Vuglinski. 2000. Historical trends in lake and river ice cover in the Northern Hemisphere. Science, 289: 1743-1746.

Megard, R.O. 1967. Three new species of Alona (Cladocera, Chydoridae) from the United States. Int. Rev. ges. Hydrobiol., 52: 37-50.

Moore, J.W. 1978. Composition and structure of zooplankton communities of 18 arctic and subarctic lakes. Int. Rev. ges. Hydrobiol., 63: 545-565.

Moore, M.V. C.L. Folt \& R.S. Stemberger. 1996. Consequences of elevated temperatures for zooplankton assemblages in temperate lakes. Arch. Hydrobiol., 135: 289-319.

O'Brien, W.J. 2001. Long-term impact of an invertebrate predator, Heterocope septentrionalis, on an arctic pond zooplankton community. Freshwat. Biol., 46: 39-45.

O'Brien, W.J., M. Barfield, N. Bettez, A.E. Hershey, J.E. Hobbie, G. Kipphut, G. Kling \& M.C. Miller. 2005. Longterm response and recovery to nutrient addition of a partitioned arctic lake. Freshwat. Biol., 50: 731-741.

O'Brien, W.J., M. Barfield, N.D. Bettez, G.M. Gettel, A.E. Hershey, M.E. McDonald, M.C. Miller, H., Mooers, J. Pastor, C. Richards \& J. Schuldt. 2004. Physical, chemical, and biotic effects on arctic zooplankton communities and diversity. Limnol. Oceanogr., 49: 1250-1261.

Overland, J.E., M.C. Spillane \& N.N. Soreide. 2004. Integrated analysis of physical and biological pan-Arctic change. Clim. Change, 63: 291-322.

Patalas, K. 1990. Diversity of the zooplankton communities in Canadian lakes as a function of climate. Verh. Int. Ver. Theor. Angew. Limnol., 24: 360-368.

Persaud, A.D. \& C.E. Williamson. 2005. Ultraviolet and temperature effects on planktonic rotifers and crustaceans in northern temperate lakes. Freshwat. Biol., 50: 467-476.

Pienitz, R., J.P. Smol \& D.R.S. Lean. 1997. Physical and chemical limnology of 24 lakes located between Yellowknife and Contwoyto Lake, Northwest Territories (Canada). Can. J. Fish. Aquat. Sci., 54: 347-358.

Prowse, T.D., F.J. Wrona, J.D. Reist, J.J. Gibson, J.E. Hobbie, L.M.J. Lévesque \& W.F. Vincent. 2006. Climate change effects on hydroecology of arctic freshwater ecosystems. Ambio. 35: 347-358. 
Quinlan, R. \& J.P. Smol. 2001. Setting minimum head capsule abundance and taxa deletion criteria in chironomid-based inference models. J Paleolimnol., 26: 327-342.

Rautio, M. \& A. Korhola. 2002. Effects of ultraviolet radiation and dissolved organic carbon on the survival of subarctic zooplankton. Polar Biol., 25: 469-473.

Reed, E.B. 1959. The distribution and ecology of freshwater Entomostraca in arctic and subarctic North America. Ph.D. thesis. University of Saskatchewan, Saskatoon, Saskatchewan, Canada: 152 pp.

Ritchie, J.C. 1993. Northern vegetation. In: H.M. French \& O. Slaymaker (Eds), Canada's Cold Environments. McGillQueen's University Press, Montreal and Kingston: 93-116.

Rühland, K. 2001. Diatom assemblage shifts relative to changes in environmental and climatic conditions in circumpolar treeline regions of the Canadian and Siberian Arctic. Ph.D. dissertation, Queen's University, Kingston, Ontario, Canada: 278 pp.

Rühland, K. \& J.P. Smol. 1998. Limnological characteristics of 70 lakes spanning Arctic treeline from Coronation Gulf to Great Slave Lake in the Central Northwest Territories, Canada. Int. Rev. ges. Hydrobiol., 83: 183-203.

Rühland, K. \& J.P. Smol. 2002. Diatom-limnological relationships in 77 lakes from the central Canadian treeline region: Development of diatom-based inference models for reconstructions of long-term environmental change. $J$. Phycol., 38: 249-254.

Rühland, K., R. Pienitz \& J.P. Smol. 2003a. Ecology and spatial distribution of surface-sediment diatoms from 77 lakes in the Subarctic Canadian treeline region. Can. J. Bot., 81: 57-73.

Rühland, K., J.P. Smol, D. Muir \& X. Wang. 2003b. Limnological characteristics of 56 lakes in the central Canadian Arctic treeline region. J. Limnol., 62(1): 9-27.

Rühland, K., A. Priesnitz \& J.P. Smol. 2003c. Paleolimnological evidence from diatoms for recent environmental changes in 50 lakes across Canadian Arctic treeline. Arct. Antarct. Alp. Res., 35: 110-123.

Sarmaja-Korjonen, K. M. Hakojärvi \& A. Korhola. 2000. Subfossil remains of an unknown chydorid (Anomopoda: Chydoridae) from Finland. Hydrobiologia, 436: 165-169.

Sarmaja-Korjonen, K., M. Nyman, S. Kultti \& M. Valiranta. 2006. Palaeolimnological development of Lake Njargajavri, northern Finnish Lapland, in a changing Holocene climate and environment. J. Paleolimnol., 35: 65-81.

Serreze, M.C. \& J.A. Francis. 2006. The arctic amplification debate. Clim. Change, 76: 241-264.

Serreze, M. C., J.E. Walsh, F.S. Chapin, III, T. Osterkamp, M. Dyurgerov, V. Romanovsky, W.C. Oechel, J. Morison, T. Zhang \& R.G. Barry. 2000. Observational evidence of recent change in the northern high-latitude environment. Clim. Change, 46: 159-207.

Sirois, L. 1992. The transition between boreal forest and tundra. In: Shugart, H.H., R. Leemans \& G.B. Bonan (Eds), $A$ System Analysis of the Global Boreal Forest. Cambridge University Press, Cambridge: 196-215.

Smirnov, N.N. 1974. Fauna of the U.S.S.R. Crustacea. Chydoridae. Volume 1, Number 2. Israel Program for Scientific Translations, Jerusalem: $644 \mathrm{pp}$.

Smirnov, N.N. 1996. Cladocera: the Chydorinae and Sayciinae (Chydoridae) of the world. Guides to the identification of the microinvertebrates of the continental waters of the world. SPB Academic Publishing. Amsterdam: $197 \mathrm{pp}$.

Smith, L.C., Y. Sheng, G.M. MacDonald \& L.D. Hinzman. 2005. Disappearing arctic lakes. Science, 308: 1429.

Smol, J.P. \& M.S.V. Douglas. 2007a. From controversy to consensus: making the case for recent climatic change in the Arctic using lake sediments. Front. Ecology Environ., 5: 466-474.
Smol, J.P. \& M.S.V. Douglas, 2007b. Crossing the final ecological threshold in high Arctic ponds. Proc. Nat. Acad. Sci., 104: 12395-12397.

Smol, J.P., A.P. Wolfe, H.J.B. Birks, M.S.V. Douglas, V.J. Jones, A. Korhola, R. Pienitz, K. Rühland, S. Sorvari, D. Antoniades, S.J. Brooks, M.-A. Fallu, M. Hughes, B. Keatley, T. Laing, N. Michelutti, L. Nazarova, M. Nyman, A.M. Paterson, B. Perren, R. Quinlan, M. Rautio, E. Saulnier-Talbot, S. Siitonen, N. Solovieva \& J. Weckström. 2005. Climate-driven regime shifts in Arctic lake ecosystems . Proc. Nat. Acad. Sci., 102: 4397-4402.

Stemberger, R.S., A.T. Herlihy, D.L. Kugler, \& S.G. Paulsen. 1996. Climate forcing on zooplankton richness in lakes of the northeastern United States. Limnol. Oceanogr., 41: 1093-1101.

Swadling, K.M., R. Pienitz, \& T. Nogrady. 2000. Zooplankton community composition of lakes in the Yukon and Northwest Territories (Canada): relationship to physical and chemical limnology. Hydrobiologia, 431: 211-224.

Sweetman, J.N. \& J.P. Smol. 2006a. Patterns in the distribution of Cladocerans (Crustacea: Branchiopoda) in lakes across a north-south transect in Alaska, USA. Hydrobiologia, 553: 277-291.

Sweetman, J.N. \& J.P. Smol. 2006b. Reconstructing fish populations using Chaoborus (Diptera: Chaoboridae) remains - a review. Quat. Sci. Rev., 25: 2013-2023.

Sweetman, J.N. \& J.P. Smol. 2006c. A guide to the identification of cladoceran remains (Crustacea, Branchiopoda) in Alaskan lake sediments. Arch. Hydrobiol. (Supplement), 151: 353-394.

Sweetman, J.N., E. LaFace, K.M. Rühland \& J.P. Smol. 2008. Evaluating the response of Cladocera to recent environmental change in lakes from the Canadian Arctic treeline region. Arct. Antarct. Alp. Res., 40: 584-591.

ter Braak, C. J. F., \& P. Šmilauer. 2002. CANOCO reference manual and CanoDraw for Windows user's guide: software for canonical community ordination. (Version 4.5) Microcomputer Power, Ithaca, New York, USA.

Tremel, B., S.E. Frey, N.D. Yan, K.M. Somers \& T.P. Pawson. 2000. Habitat specificity of littoral Chydoridae (Crustacea, Branchiopoda, Anomopoda) in Plastic Lake, Ontario, Canada. Hydrobiologia. 432: 195-205.

Vandekerkhove, J., S. Declerck, L. Brendonck, J.M. CondePorcuna, E. Jeppesen, L. Sander Johansson, \& L. De Meester. 2005. Uncovering hidden species: hatching diapausing eggs for the analysis of cladoceran species richness. Limnol. Oceanogr. Meth., 3: 399-407.

Walker, I.R., A.J. Levesque, R. Pienitz, R. \& J.P. Smol. 2003. Freshwater midges of the Yukon and adjacent Northwest Territories: a new tool for reconstructing Beringian paleoenvironments? J.N. Am. Benthol. Soc., 22: 323-337.

Wedel, J.H., A. Smart \& P. Squires. 1990. An Overview Study of the Yellowknife River Basin, N.W.T. N.W.T. Programs. Inland Waters Directorate Conservation and Protection, Western and Northern Region, Environment Canada.

Williamson, C.E., O.G. Olson, S.E. Lott, N.D. Walker, D.R. Engstom \& B.R. Hargreaves. 2001. Ultraviolet radiation and zooplankton community structure following deglaciation in Glacier Bay, Alaska. Ecology, 82: 1748-1760.

Wissel, B., W.J. Boeing, \& C.W. Ramcharan. 2003. Effects of water color on predation regimes and zooplankton assemblages in freshwater lakes. Limnol. Oceanogr., 48: 1965-1976.

Zellmer, I.D., M.T. Arts, D. Abele, \& K. Humbeck. 2004. Evidence of sublethal damage in Daphnia (Cladocera) during exposure to solar UV radiation in subarctic ponds. Arct. Antarct. Alp. Res., 36: 370-377.

Received: July 2009

Accepted: October 2009 